\title{
Antibacterial Characterization Studies of Silver Nanoparticles against Staphylococcus aureus and Escherichia coli
}

\author{
Sahar E. Abo-Neima and Sohair M. El-kholy* \\ Physics Department, Faculty of Science, Damanhour University, \\ Mansoura, Elbehera and *Medical Biophysics Department, Medical \\ Research Institute, Alexandria University, Alexandria, Egypt.
}

\begin{abstract}
T HE PRESENT study was performed to investigate the antibacterial activities of silver nanoparticles (Ag-NPs) between gram negative Escherichia coli (E. coli) and gram positive Staphylococcus aureus (S. aureus) bacteria. The activity of Ag-NPs synthesized by physical method, this study was performed by observing the bacterial cells treated or not with Ag-NPs on bacterial conductivity, antibiotic susceptibility, molecular and morphological cellular structure by transmission TEM as results indicated that E.Coli and $S$. aureus treated with Ag-NPs can inhibit bacterial growth and significant increase in antibiotic susceptibility to protein, cell wall and DNA inhibitors. Results of dielectric relaxation and TEM indicated molecular and morphological changes. It will be concluded that AgNPs could be used as an excellent effective antimicrobial material on microorganisms.
\end{abstract}

Keywords: $S$.aureus, E. coli, Ag-NPs, TEM, Antibiotic susceptibility, DNA, Dielectric relaxation.

Human beings are often infected by different types of microorganisms such as yeasts, viruses and bacteria which are present in their living environments. Over the past years, antimicrobial resistance is an increasing problem worldwide, impacting infection control efforts and costs of antimicrobial treatment. Scientifics have researched method to overcome the resistances of microorganisms to antibiotics.

Nanotechnology nowadays has the ability to offer the opportunity to fight microbial infections via synthesis of nanoparticles. The mechanism of prevention of bacterial growth by antibiotics is quite different from the mechanisms by which nanoparticles inhibit microbial growth. Therefore, nanoparticles have the potential to serve as an alternative to antibiotics and to control microbial infections $^{(1,2)}$.

Recent studies have demonstrated that specially formulated metal oxide nanoparticles have good antibacterial activity and antimicrobial formulations comprising nanoparticles could be effective bactericidal materials ${ }^{(3,4)}$.

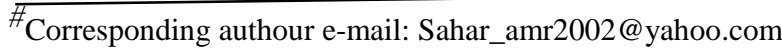


Synthesis of nanosized drug particles with tailored physical and chemical properties is of great interest in the development of new pharmaceutical products. Silver is a nontoxic, safe inorganic antibacterial agent and is capable of killing about 650 types of diseases causing microorganisms and its ability to exert a bactericidal effect at minute concentrations ${ }^{(5,6)}$. Silver has the advantage of having broad antimicrobial activities against Gram-negative and Gram-positive bacteria and there is also minimal development of bacterial resistance ${ }^{(7,8)}$.

Silver ions have long been known to have strong inhibitory and bactericidal effects as well as a broad spectrum of antimicrobial activities; Some forms of silver have been demonstrated to be effective against burns, severe chronic osteomvelitis, urinary tract infections, and central venous cotheter infections ${ }^{(9)}$.

The antimicrobial activity of silver has been recognized by clinicians for over 100 years ${ }^{(10)}$. In addition, many reports suggested that hygienic benefits have been associated with the use of silver for considerably longer time In the same time, records showed that Hippocrates recognized the role of silver in the prevention of disease and the Romans stored wine in silver vessels to prevent spoilage. However, only in the last few decades the mode of action of silver as an antimicrobial agent has been studied without any rigour ${ }^{(11)}$.

Silver has a significant potential for a wide range of biological applications such as antifungal agent, antibacterial agents for antibiotic resistant bacteria, preventing infections, healing wounds and anti-inflammatory ${ }^{(3)}$. Silver ions $\left(\mathrm{Ag}^{+}\right)$ and its compounds are highly toxic to microorganisms exhibiting strong effects on many species of bacteria but have a low toxicity towards animal cells. Therefore, silver ions, being as antibacterial component, silver ions inhibited cell division and damaged the cell envelope and cellular contents of the bacteria ${ }^{(12)}$.

The size of the bacterial cells increased the cytoplasmic membrane, cytoplasmic contents and the outer cell layers exhibit abnormalities. In addition ionic silver strongly interacts with thiol groups of vital enzymes and with the bases in the DNA and inactivates them so that DNA loses its replication ability once the bacteria are treated with silver ions ${ }^{(13,14)}$ and the bacterial cell death.The effects of Ag-NPs on the morphological structural of bacterial cells were observed by TEM.

The main objective of this work to study the interaction between bacteria and silver nanoparticle to evaluate the antibacterial activity of Ag-NPs against bacteria. It appears that the combined toxic effect of silver and hydrogen peroxide may be related with damage to cellular proteins. However, the mechanism of antimicrobial effects of silver is still not fully understood. The effects of silver ions on bacteria may be complicated; however direct observation of the morphological and structural changes may provide useful information for understanding the comprehensive antibacterial effects and the process of inhibition of silver ions

Egypt. J. Biophys. Biomed. Engng. Vol. 17 (2016) 


\section{Materials and Methods}

Experimental system materials used to prepare colloidal silver

Silver wires (Gredmann , 99.99\%, $1 \mathrm{~mm}$ in diameter) and submerged in deionized water the DC arc-discharge system consists of two silver electrodes $1 \mathrm{~mm}$ in diameter, servo control system which maintains a constant distance between the electrodes, power supply system which controls the DC arcdischarge parameters and Glass container with an electrode holder and deionized water to collect the silver colloids ${ }^{(15)}$.

\section{Preparation of silver nanoparticles suspension in pure water}

The power supply system provides a stable pulse voltage for etching the silver electrodes in pure water. Silver wires are used as both the positive and negative electrodes; the pure silver wires are etched by the DC pulse arcdischarge in pure water ${ }^{(16)}$. During silver nanoparticle production by arc discharge in water, water decomposition (e.g. electrolysis) was also observed. This results in generation of gaseous hydrogen and oxygen, which appear in the water as small bubbles partly dissolved in the water medium. Hydrogen and oxygen start to interact with the newly prepared silver nanoparticles. Since hydrogen (molecular or atomic forms) does not adsorb on silver particle surfaces at room temperature ${ }^{(17)}$ and also is not significantly dissolved in water, it is ultimately removed from the water suspension to the gas phase. An Electricity Generator such as $13.5 / 30 \mathrm{~V}$ AC power adapter 40 watt (Fig.1). Two insulated alligator clips to replace the plug on the end of the power adapter. Two $12 \mathrm{~cm}$ lengths of $99.99 \%$ of pure silver strips. $100 \mathrm{ml}$ glass jar (Fig. 2).

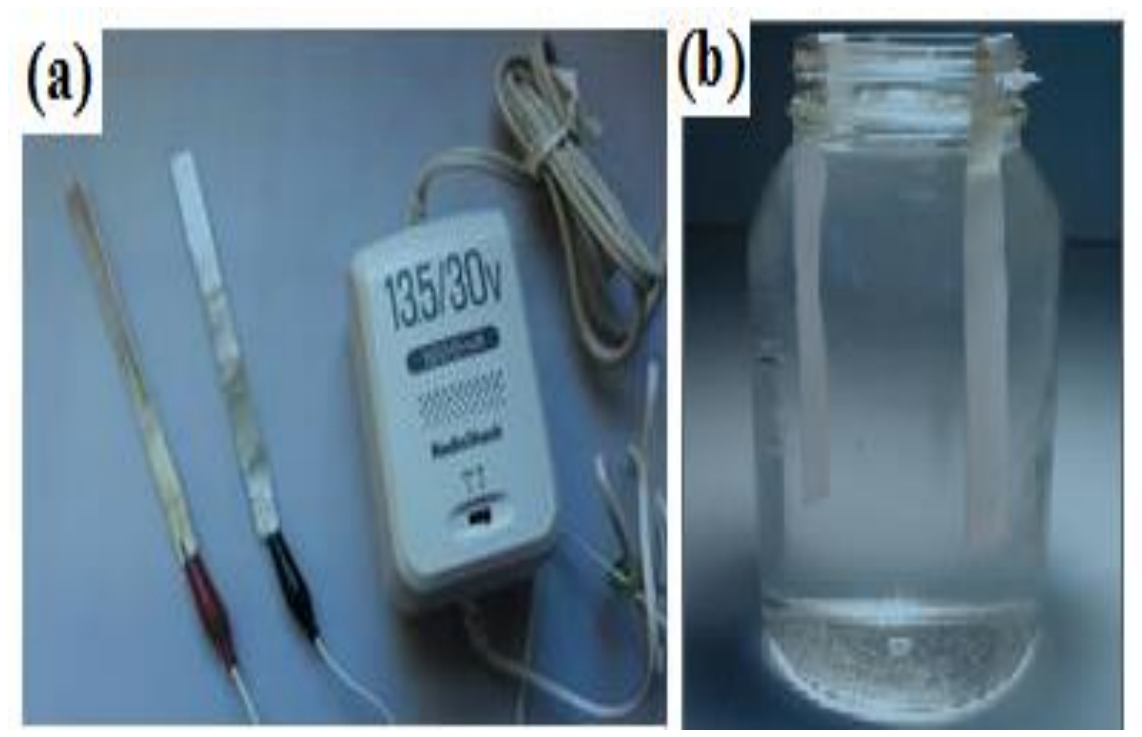

Fig. 1. (a) Power supply (b) Glass jar. 
Bacterial strains, reagents and cultivation

The S. aureus (ATCC\# 25923) and E.coli (ATCC\# 25922) cells used in the present study were supplied by Ocology Center in Damanhour, Egypt. MullerHinton broth (Becton Dickinson, U.S.A) and Muller-Hinton agar (Becton Dickinson, U.S.A) were used as a culture media. Muller-Hinton broth contains beef extract powder, and acid digest of casein, and soluble starch. Muller-Hinton agar contains agar in addition to the above reagents mentioned in Muller-Hinton broth composition ${ }^{(18,12)}$. All other reagents used were of the purest grade commercially available.

Growth curve of bacterial cells treated with Ag-Nps

To study the growth curves of bacterial cells exposed to Ag-NPs, MullerHinton broth with concentration $0.046 \mathrm{gm} /$ mole of Ag-NPs was used, and the bacterial cell concentration was adjusted to $10^{6} \mathrm{CFU} / \mathrm{ml}^{(12)}$. Each culture was incubated in a shaking incubator at $37^{\circ} \mathrm{C}$ for $24 \mathrm{hr}$. Growth curves of bacterial cell cultures were attained through repeated measures of the optical density (O.D) at $600 \mathrm{~nm}$ using a spectrophotometer model (UV/visible spectrophotometer LKB-Nova spec, made in England), and the concentration of cells (number of cells CFU/ml) was determined by plate counting technique and appropriate dilutions of the bacterial cells were used to inoculate nutrient agar plates. Inoculated plates were then incubated at $37^{\circ} \mathrm{C}$ for $24 \mathrm{hr}$ by counting the number of colonies developed after incubation and multiplying it with the dilution factor the number of cells in the initial population is determined with $\mathrm{CFU} / \mathrm{ml}{ }^{(2)}$.

\section{Transmission electron microscopy (Tem)}

A $\log$ phase culture of $S$. aureus \& E. coli NCTC4163 in Mueller-Hinton broth was split into $1.5 \mathrm{~mL}$ aliquots. The cells were collected by centrifugation (10000 rpm, $5 \mathrm{~min}$ ) and resuspended in peptone water. Six samples were prepared; two untreated, two treated with SMAP29 $(4 \mathrm{lg} / \mathrm{mL})$ and two treated with $\mathrm{OaBac} 5 \operatorname{mini}(64 \mathrm{lg} / \mathrm{mL})$. The samples were incubated at $37^{\circ} \mathrm{Cfor} 1 \mathrm{hr}$. The cells were collected by centrifugation (10000 rpm, $5 \mathrm{~min}$ ) to remove the peptone water. To fix the cells, $2 \%$ glutaraldehyde in $0.1 \mathrm{M}$ cacodylate was added and the samples were incubated at $4^{\circ} \mathrm{Cfor} 1 \mathrm{hr}$. The cells were collected by centrifugation (10000 rpm, $5 \mathrm{~min}$ ) and washed twice with $0.1 \mathrm{M}$ phosphate buffer. To postfix the cells, $1 \%$ osmium tetraoxide was added and the samples were left at room temperature for $1 \mathrm{hr}$. The samples were dehydrated with graded ethanol solutions (30\% ethanol for $10 \mathrm{~min}, 60 \%$ ethanol for $10 \mathrm{~min}, 90 \%$ ethanol for $10 \mathrm{~min}, 100 \%$ ethanol for $10 \mathrm{~min}, 100 \%$ ethanol for $1 \mathrm{hr}$ ), embedded in Procure 812 resin and left to polymerise (over the weekend). From each sample 10 thin slices (approximately $100 \mathrm{~nm}$ ) were cut with a diamond knife and stained with uranyl acetate and lead citrate on grids. Each of these sections was examined with a Philips EM201 $80 \mathrm{kV}$ Transmission Electron Microscope and images were taken with a $35-\mathrm{mm}$ camera $^{(19,20)}$.

Egypt. J. Biophys. Biomed. Engng. Vol. 17 (2016) 


\section{Antibiotic susceptibility test (AST)}

S. aureus and E.coli bacterial cells were tested for their in vitro susceptibility to various antibiotics using the agar diffusion method. The antibiotics used in this study were chosen to represent different modes of action. These discs were

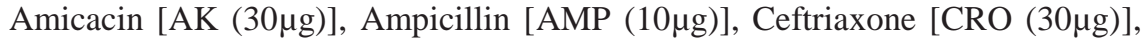

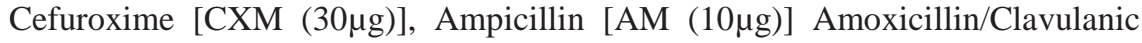

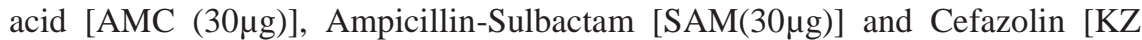
$(30 \mu \mathrm{g})]$ which inhibit cell wall synthesis. Also, Ciprofloxacin [CIP $(5 \mu \mathrm{g})]$, Ofloxacin [OFX $(5 \mu \mathrm{g})]$, and Norfloxacin [NOR $(10 \mu \mathrm{g})]$ which are inhibitors for bacterial DNA. In addition to $[\mathrm{E}(15 \mu \mathrm{g})]$, Streptomycin $[\mathrm{S}(10 \mu \mathrm{g})]$ and Chloramphenicol $[\mathrm{C}(30 \mu \mathrm{g})]$ which are inhibitors for the proteins. After plate inoculation and incubation at $37^{\circ} \mathrm{C}$ for $24 \mathrm{hr}$, the diameters of the inhibition or stimulation zone of exposed and unexposed cells were measured in $\mathrm{mm}$.

\section{Dielectric measurements for the bacterial cells}

For measurement a bacterial sample $(1 \mathrm{ml})$ was placed into sterile micro centrifuge tube and centrifuged at $14,000 \mathrm{rpm}$ at $4^{\circ} \mathrm{C}$ for $15 \mathrm{~min}$. The pellet was then harvested and resuspended in a $1 \mathrm{~mL}$ volume of sterile deionised water. The tube was then centrifuged and the pellet was washed with deionised water twice more, before finally being resuspended in sterile deionised water. A fixed concentration of bacterial cells $1 \times 10^{6}(\mathrm{CFU} / \mathrm{mL})$ was used for all samples which were controlled through the use of the spectrophotometer. The dielectric measurements were carried out for the samples in the frequency range $42 \mathrm{~Hz}-$ $5 \mathrm{MHz}$ using a loss Factor Meter type HIOKI 3532 LCR Hi TESTER; version 1.02, Japan, and cell types (PW 950/60) manufactured by Philips. The cell has two parallel square platinum black electrodes of $0.8 \mathrm{~cm}$ side each, and area $0.64 \mathrm{~cm}^{2}$, with an inter-electrode distance of $1 \mathrm{~cm}$. During the measurements both the cell and the sample were kept at $25^{\circ} \mathrm{C}$ in an incubator (Kottermann type 2771, Germany). Each run was repeated three times. The measured values of capacitance, $\mathrm{C}$ and resistance, $\mathrm{R}$, were used to calculate real ${ }^{\varepsilon^{\prime}}$ (dielectric constant) from Equation (1) and imaginary parts $E^{\prime \prime}$ (dielectric loss) of the complex permittivity from Equation (2). The conductivity $\sigma$ was calculated from the Equation (3) ${ }^{(21)}$.

$$
\begin{gathered}
\varepsilon^{\prime}=\frac{C d}{\varepsilon_{0} A} \\
\varepsilon^{\prime \prime}=\frac{\varepsilon^{\prime}}{2 \pi f R C} \\
\sigma=2 \pi f \varepsilon^{\prime \prime} \varepsilon_{0}
\end{gathered}
$$




\section{Statistical analysis}

All experiments were repeated at least three times and the statistical significance of each difference observed among the mean values was determined by standard error analysis. The results were represented as means \pm SD. Data from bacterial growth studies were compared using Student T-test and ANOVA analysis, the level of significance was set at $p<0.05$, which was considered statistically significant ${ }^{(22,23)}$.

\section{Results and Discussion}

Growth curves of bacterial cells treated with Ag-NPs

The growth curves of bacterial cells treated with Ag-NPs indicated that AgNPs could inhibit the growth. The growth curve of treated with Ag-NPs $S$. aureus cells are shown in Fig. 1(A\&B). The growth curve of E.coli cells treated with Ag-NPs is shown in Fig. 2 (A\&B). The results indicate that the antibacterial activity of Ag-NPs could inhibit the bacterial growth. The bacterial cell colonies on agar-plates were detected by viable cell counts. Viable cell counts are the counted number of colonies that are developed after a sample has been diluted and spread over the surface of a nutrient medium solidified with agar and contained in a petri dish. The number of CFU reduced significantly by using silver nanoparticles. The bacterial growth inhibition trend observed from CFU data has matched well with the results of optical density
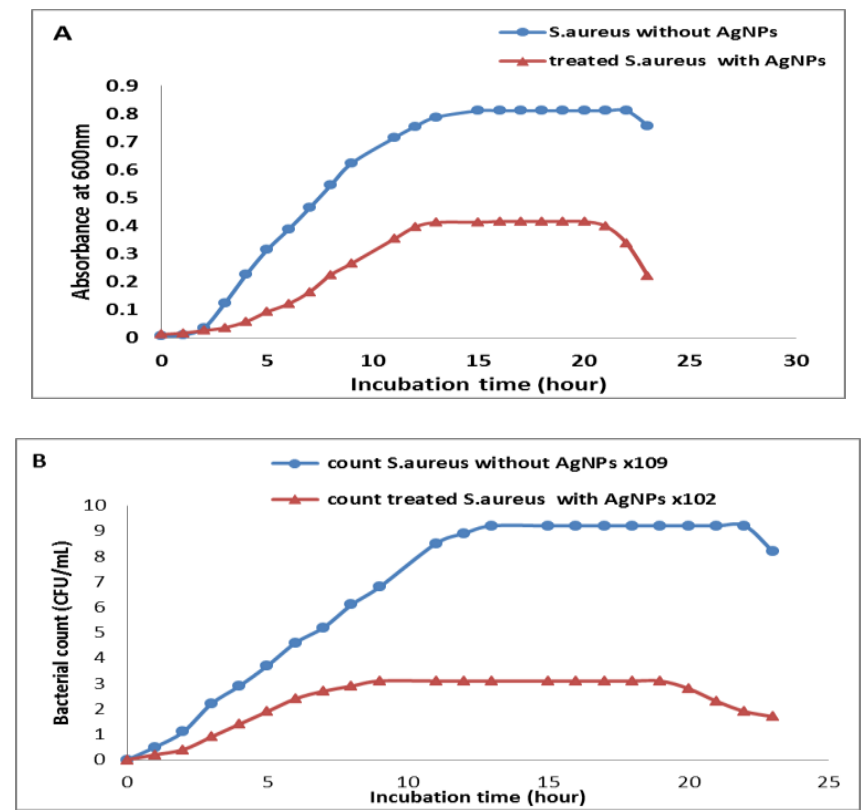

Fig. 1. (A\&B). Growth curves of S. aureus cells exposed to Ag-NPs at normal condition.

Egypt. J. Biophys. Biomed. Engng. Vol. 17 (2016) 

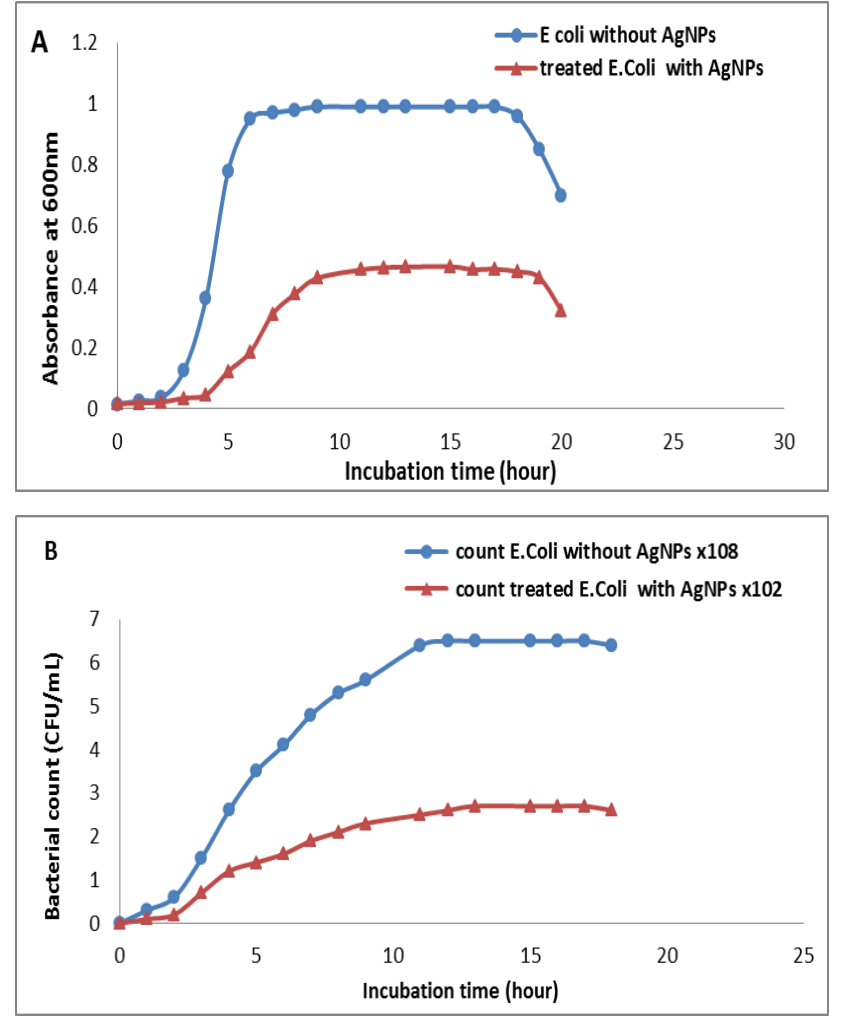

Fig. 2. (A\&B). Growth curves of E.Coli cells exposed to Ag-NPs at normal condition.

TEM analysis for silver nano-particles

Figure3 shows the TEM image of the colloidal silver nanoparticles, the size were investigated by TEM which indicates that silver particles are ranged from $26-40 \mathrm{~nm}$ average diameter and spherical shape in a magnification $\times 75$. Figure 4 shows the image of the Colloidal silver nanoparticles of total magnification x 150 .

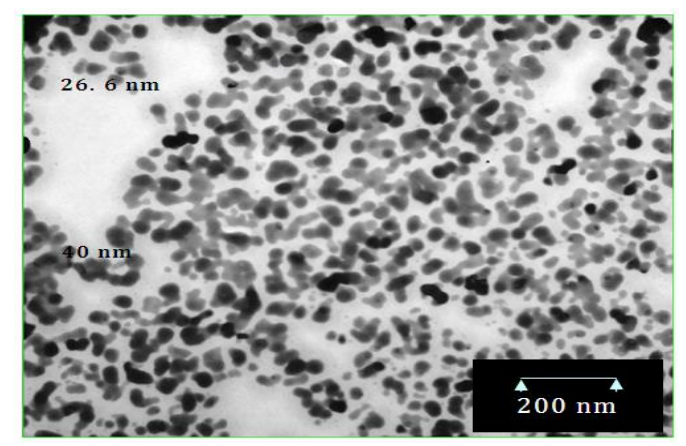

Fig.3.Colloidal silver nanoparticles identified by (TEM) magnification x 70 .

Egypt. J. Biophys. Biomed . Engng. Vol. 17 (2016) 


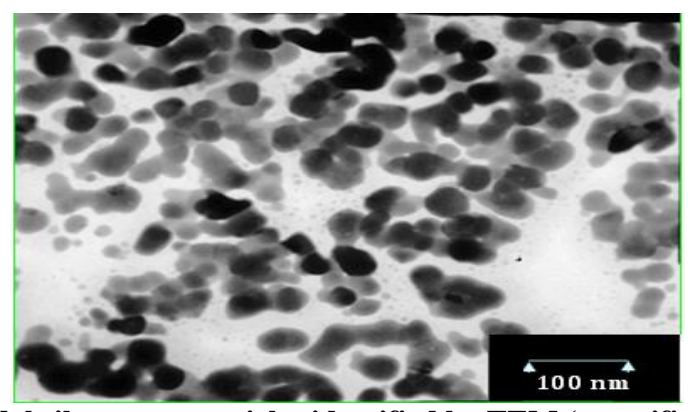

Fig.4. Colloidal silver nanoparticles identified by TEM (magnification $x$ 150).

Effects of Ag-NPs on morphology of bacterial cells

The morphological changes of bacterial cells were observed by TEM. (Fig.5a) revealed the TEM of untreated E.coli which shows normal structure of cell membrane but $E$. coli treated with Ag-NPs (Fig. 5b,c,d) showed an accumulations of membranous structure in the cytoplasm of the biocides treated cells, and there is no external morphological alternations were seen in the cells. The cytoplasm shows granularity with regions where DNA fibrils are evident. Also coagulate material were seen inside the treated cells. (Fig.4). Revealed the TEM micrograph of untreated S.aureus which shows a dark area where the sample had a high electron density. The morphological investigation of the samples treated with Ag-NPs were greatly different to those of the un treated cells revealed a disintegration of the cell wall, (Fig. 6b), the light area show where the sample had a low electron density, extrusion of the cytoplasmic contents, (Fig. 6.c,d,e) revealed disruptions with release of intracellular material and losing their cytoplasm and cell ghost is an empty intact cell envelope structure devoid of cytoplasmic content including genetic material. The distortion of the physical structure of the cell could cause the expansion and destabilization of the membrane and increase membrane fluidity, which in turn increases the passive permeability and manifest itself as a leakage of various vital intracellular constituents, such as ions, ATP, nucleic acids, sugars, enzymes and amino acids. In Fig. $6(f, g, h)$ cell wall perforation with release of significant intracellular components, projections of the cell wall and release of membrane vesicles were observed. TEM micrograph shows silver nanoparticles not only adhered at the surface of cell membrane, but also penetrated inside the bacterial cells, these reveals that nanoparticles have penetrated inside the bacterial cells. Nanoparticles have larger surface area available for interactions, which enhances bactericidal effect than the large sized particles; hence they impart cytotoxicity to the microorganisms. The mechanism by which the nanoparticles are able to penetrate the bacteria is not understood completely, but studies suggest that when $E$. coli was treated with silver, changes took place in its membrane morphology that produced a significant increase in its permeability affecting proper transport through the plasma membrane, leaving the bacterial cells incapable of properly regulating transport through the plasma membrane, resulting into cell death. It is observed that silver

Egypt. J. Biophys. Biomed. Engng. Vol. 17 (2016) 
nanoparticles have penetrated inside the bacteria and have caused damage by interacting DNA. Silver tends to have a high affinity to react with different compounds ${ }^{(13)}$.
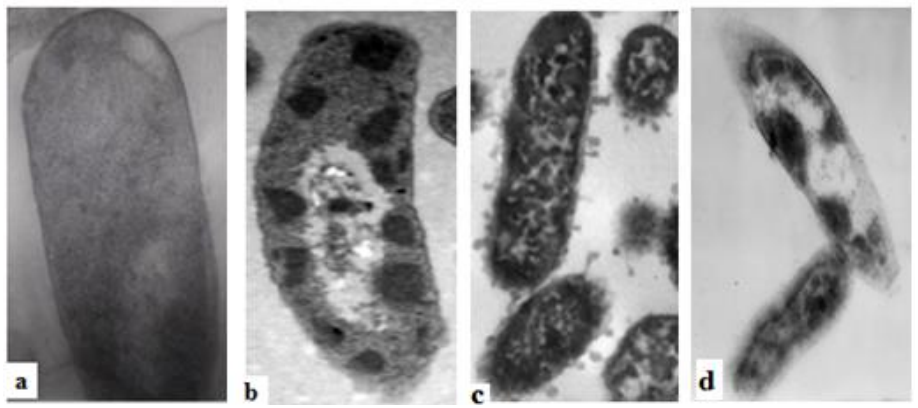

Fig.5. TEM micrographs of untreated $E$. coli (a) and $E$. coli treated with Ag-NPs (b, c, d $)($ magnification $\times 20000)$.
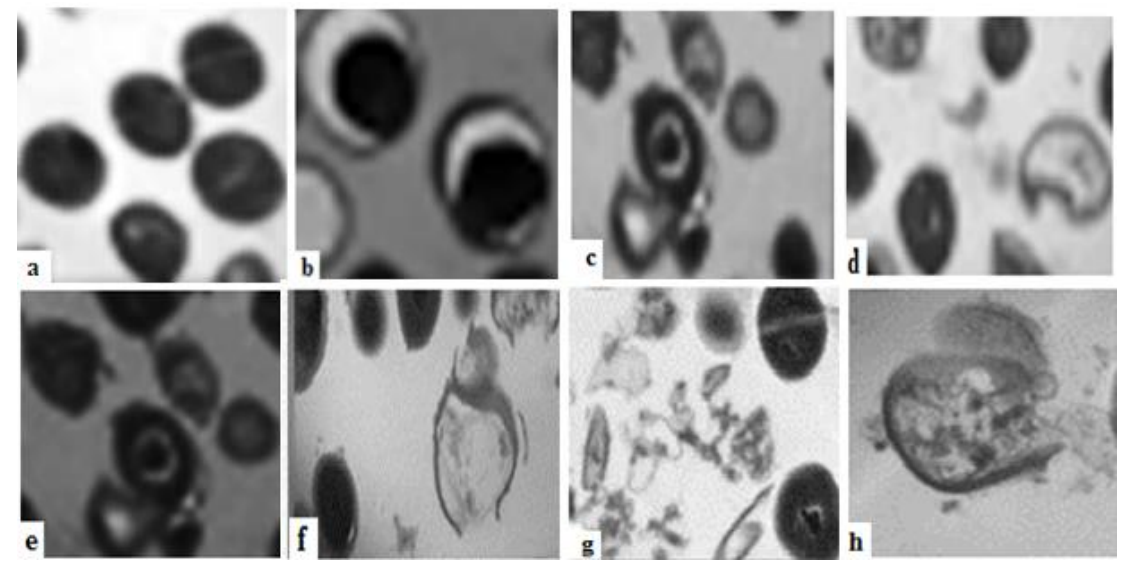

Fig.6. TEM micrographs of untreated $S$. aureus (a) and $S$.aureus treated with AgNPs $(b, c, d, e, f, g$ and $h)($ magnification $\times 20000)$.

Antimicrobial activity of silver nanoparticles

Table. 1 and 2 revealed the antibiotic sensitivity test results of $S$.aureus and E.coli are given for control samples and those treated with Ag-NPs. In this test 14 different antibiotics having different biological actions on the microorganism were used. It is clear from the Tables.1 and 2 that the sensitivity of the two microorganisms treated with AgNPs has been increased for Amicacin [AK (30 $\mu \mathrm{g})]$, Ampicillin [AMP

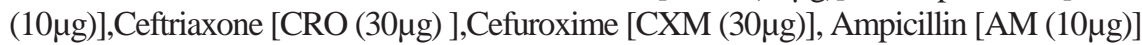
Amoxicillin/Clavulanic acid [AMC (30 $\mu \mathrm{g})]$, Ampicillin-Sulbactam $[\operatorname{SAM}(30 \mu \mathrm{g})]$ and Cefazolin $[\mathrm{KZ}(30 \mu \mathrm{g})]$ which are inhibitors for cell wall synthesis. Also, Ciprofloxacin [CIP $(5 \mu \mathrm{g})]$, Ofloxacin [OFX $(5 \mu \mathrm{g})]$, and Norfloxacin [NOR $(10 \mu \mathrm{g})]$ which are inhibitors 


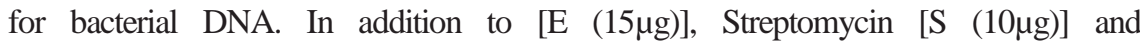
Chloramphenicol $[\mathrm{C}(30 \mu \mathrm{g})]$ which are inhibitors for the proteins. Figures 7 and 8 show inhibition zones for $S$. aureus and E. coli unexposed and treated with Ag-NPs, respectively.

TABLE 1. Antibiotic sensitivity of $S$. aureus before and after treated with Ag-NPs (Mean inhibition zone diameter in $\mathbf{m m}$ ).

\begin{tabular}{|l|c|c|}
\hline Antibiotics & Before treated & Treated \\
\hline \multicolumn{3}{|c|}{ Cell wall inhibitors } \\
\hline AMP & $11 \pm 0.31$ & $13 \pm 0.22$ \\
\hline CRO & $7 \pm 0.14$ & $18 \pm 0.12$ \\
\hline CXM & $7 \pm 0.16$ & $11 \pm 0.11$ \\
\hline AMC & $9 \pm 0.32$ & $13 \pm 0.32$ \\
\hline AK & $18 \pm 0.53$ & $27 \pm 0.33$ \\
\hline SAM & $6 \pm 0.26$ & $11 \pm 0.12$ \\
\hline KZ & $6 \pm 0.45$ & $11 \pm 0.42$ \\
\hline CFR & $9 \pm 0.63$ & $12 \pm 0.52$ \\
\hline \multicolumn{3}{|c|}{ Protein inhibitors } \\
\hline C & $22 \pm 0.14$ & $28 \pm 0.72$ \\
\hline E & $23 \pm 0.11$ & $29 \pm 0.44$ \\
\hline S & $11 \pm 0.35$ & $19 \pm 0.54$ \\
\hline \multicolumn{3}{|c|}{ DNA inhibitors } \\
\hline NOR & $27 \pm 0.32$ & $33 \pm 0.12$ \\
\hline CIP & $21 \pm 0.6$ & $31 \pm 0.18$ \\
\hline OFX & $23 \pm 0.45$ & $28 \pm 0.12$ \\
\hline
\end{tabular}

TABLE 2. Percentage changes in refractive index of edible oils after heating four times, using normal heating and microwave exposure.

\begin{tabular}{|c|c|c|}
\hline Antibiotics & Before treated & Treated \\
\hline \multicolumn{3}{|c|}{ Cell wall inhibitors } \\
\hline AMP & $10 \pm 0.41$ & $14 \pm 0.25$ \\
\hline CRO & $7 \pm 0.64$ & $10 \pm 0.16$ \\
\hline CXM & $7 \pm 0.76$ & $8 \pm 0.14$ \\
\hline AMC & $9 \pm 0.62$ & $14 \pm 0.12$ \\
\hline AK & $11 \pm 0.13$ & $16 \pm 0.22$ \\
\hline SAM & $8 \pm 0.16$ & $20 \pm 0.23$ \\
\hline $\mathrm{KZ}$ & $8 \pm 0 . .25$ & $10 \pm 0.54$ \\
\hline CFR & $8 \pm 0.33$ & $25 \pm 0.56$ \\
\hline \multicolumn{3}{|c|}{ Protein inhibitors } \\
\hline $\mathrm{C}$ & $9 \pm 0.22$ & $16 \pm 0.36$ \\
\hline $\mathrm{E}$ & $13 \pm 0.14$ & $20 \pm 0.25$ \\
\hline$S$ & $8 \pm 0.32$ & $22 \pm 0.84$ \\
\hline \multicolumn{3}{|c|}{ DNA inhibitors } \\
\hline NOR & $7 \pm 0.42$ & $8 \pm 0.12$ \\
\hline CIP & $11 \pm 0.7$ & $30 \pm 0.18$ \\
\hline OFX & $8 \pm 0.15$ & $15 \pm 0.12$ \\
\hline
\end{tabular}

Egypt. J. Biophys. Biomed. Engng. Vol. 17 (2016) 


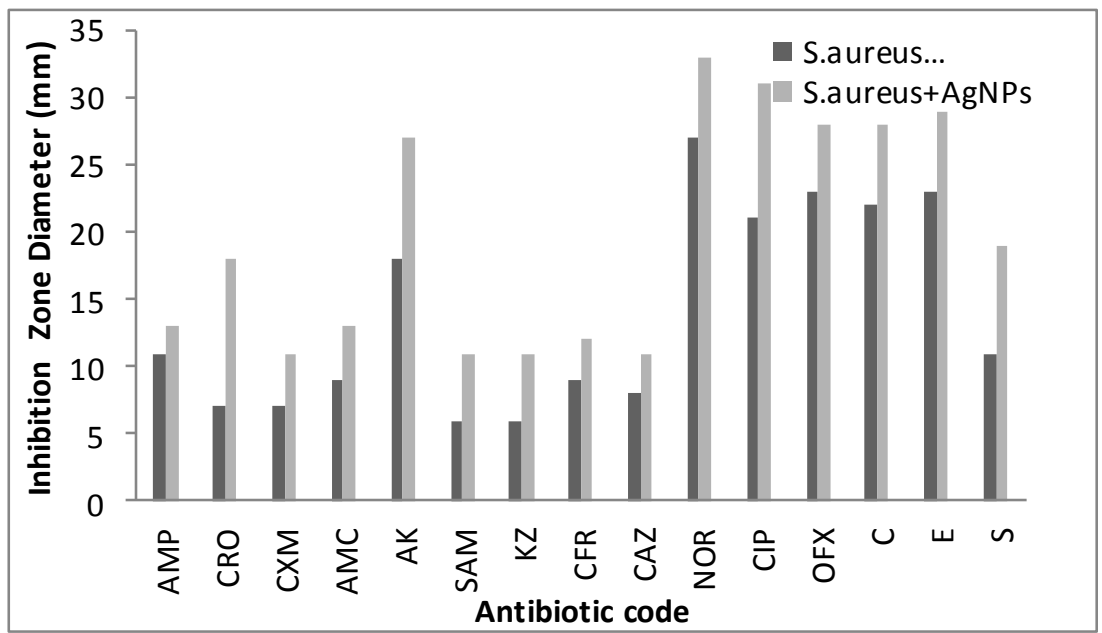

Fig. 7. Histohraph for inhibitory zone diameter for unexposed S.aureus and treated with Ag-NPs.

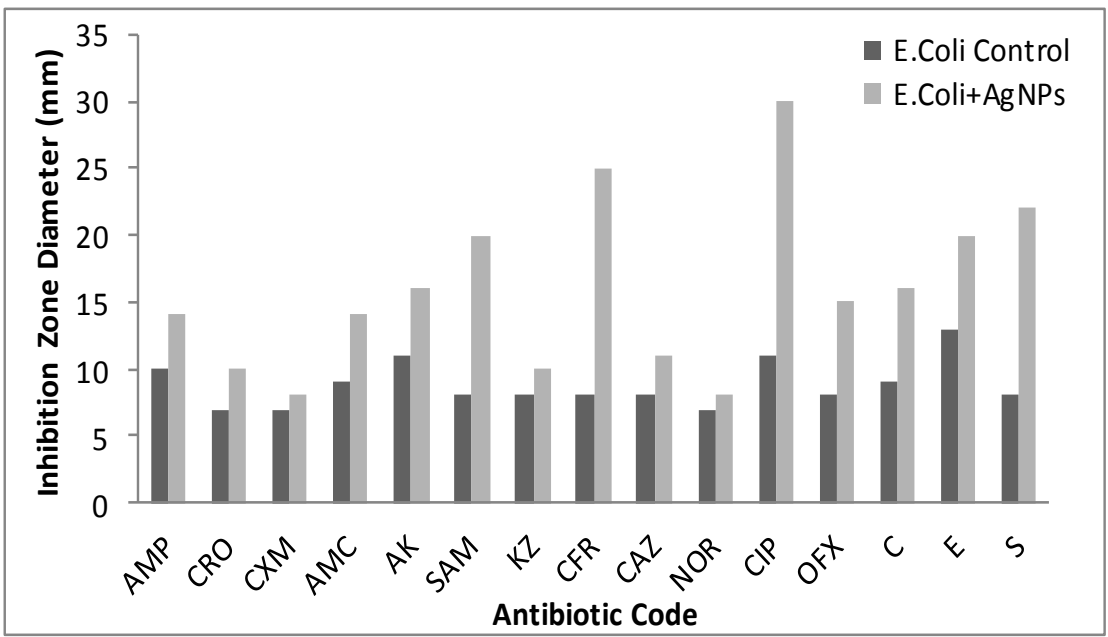

Fig. 8. Histohraph for inhibitory zone diameter for unexposed E.coli and treated with Ag-NPs

Dielectric relaxation properties

Figures 9,10 and 11,12 illustrate the variation of dielectric constant $\varepsilon^{\prime}$ and dielectric loss $\varepsilon^{\prime \prime}$ plotted in one scale (left Y-axis) and conductivity S plotted in the right $\mathrm{Y}$-axis, as a function of frequency, for both control bacterial samples and the treated with Ag-NPs. The figures show that the dielectric curves for both samples (control and treated with Ag-NPs) pass through dispersion in the frequency range $42 \mathrm{~Hz}$ to $5 \mathrm{MHz}$.Moreover, the decrease of the values of $\varepsilon^{\prime}$ as a function of the applied frequency is accompanied by increased in the values of electrical conductivity; this yields a consistency test for the data as stated by Kramers-Krong relations. The results also indicate pronounced difference in the 
values of the dielectric properties of the treated samples as compared with the control one ${ }^{(24)}$.

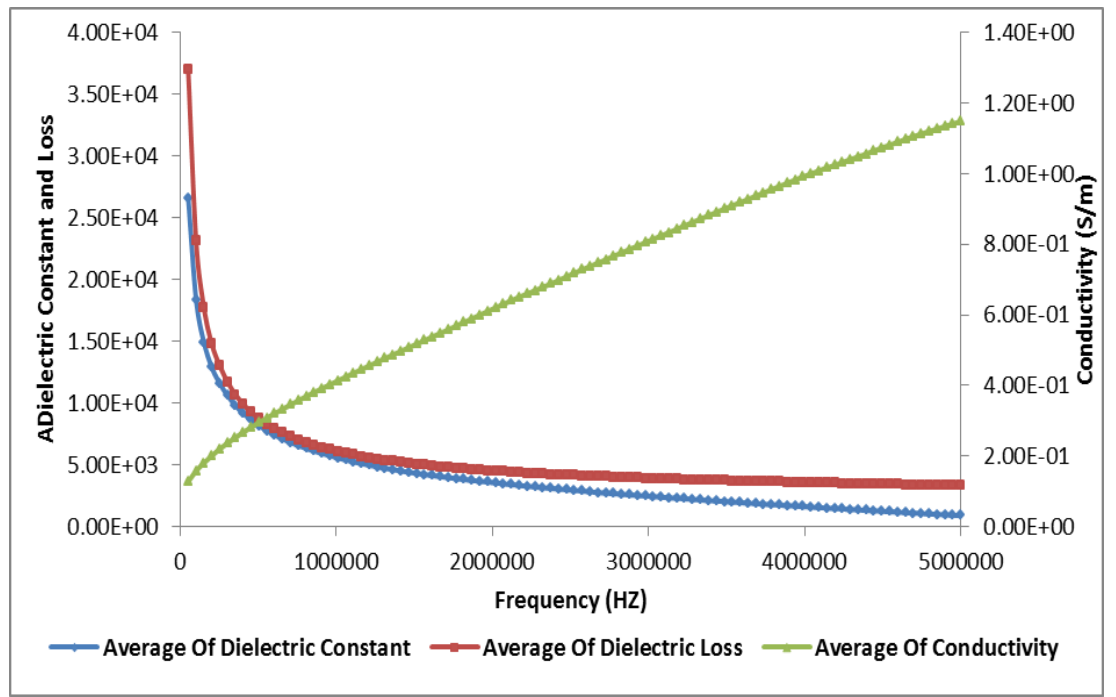

Fig.9.Dielectric behavior of control. S. aureus .

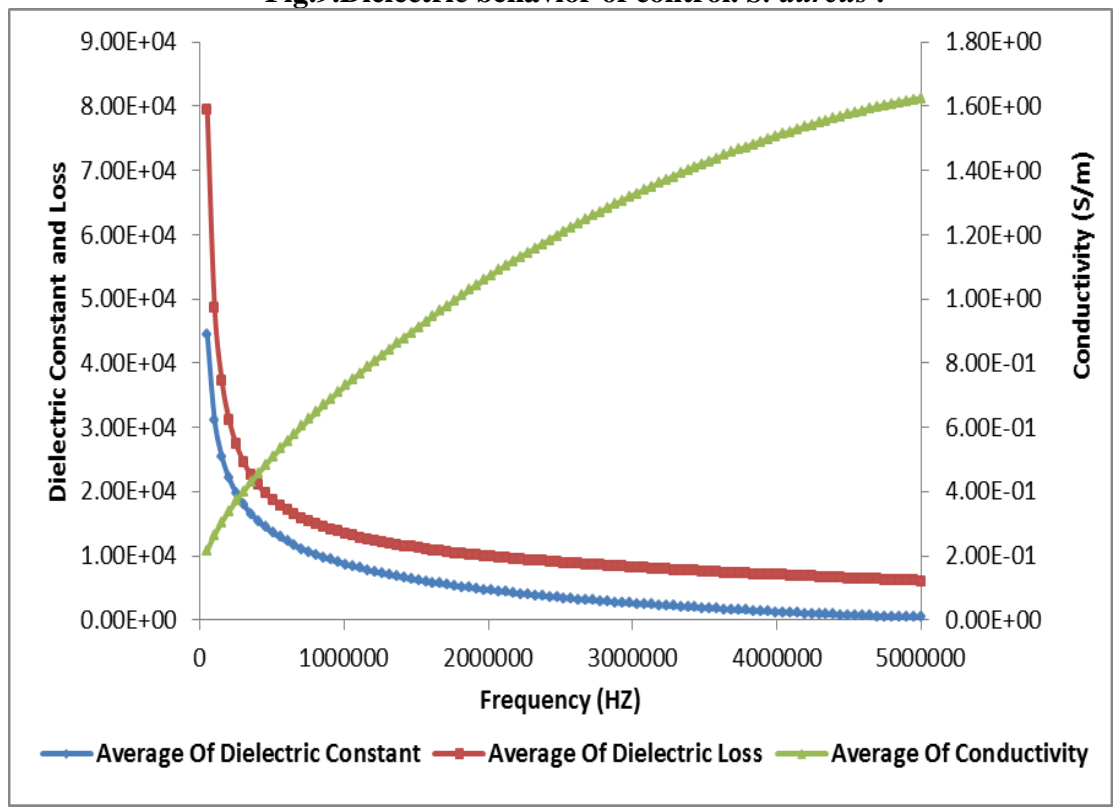

Fig.10. Dielectric behavior of S. aureus treated with Ag-NPs.

Egypt. J. Biophys. Biomed . Engng. Vol. 17 (2016) 


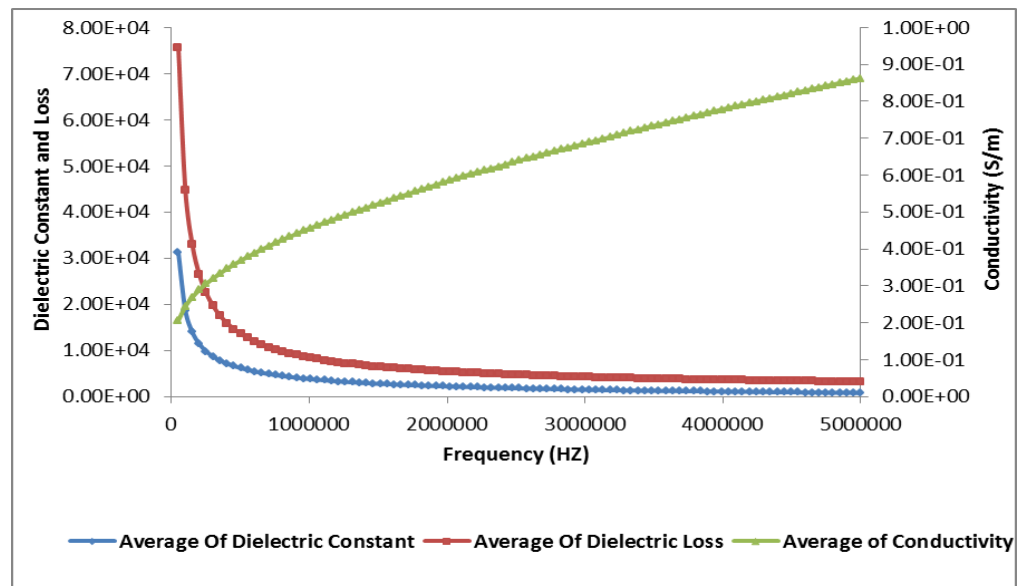

Fig. 11. Dielectric behavior of control. E.Coli .

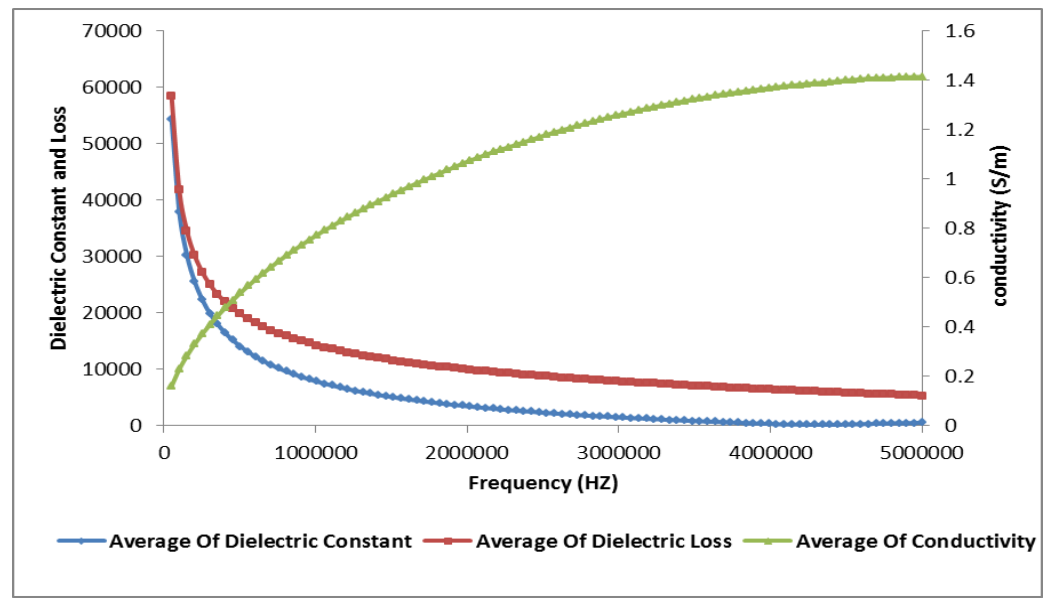

Fig.12. Dielectric behavior of E.Coli treated with Ag-NPs.

\section{Conclusion}

The results of this work can be summarized into the following:

- It is believed that silver nanoparticles after penetration into the bacteria have inactivated their enzymes, generating hydrogen peroxide and caused bacterial cell death.

- Silver nanoparticles have an excellent effect and potential in reducing bacterial growth for practical applications.

- Silver nanoparticles adhered to the cell wall of bacteria and penetrated through the cell membrane. This resulted into inhibition of bacterial cell growth and multiplication. 


\section{References}

1. Luo, P.G., Tzeng, T.R., Shah, R.R. and Stutzenberger, F.J., Nanomaterials for antimicrobial applications and pathogen detection., Curr. Trends Microbiol. 3, 111-128 (2007).

2. Ansari, M.A., Khan, H.M., Khan, A.A., Malik, A., Sultan, A., Shahid, M., Shujatullah, F. and Azam, A., Evaluation of antibacterial activity of silver nanoparticles against MSSA and MRSA on isolates from skin infections, Biology and Medicine, 3 (2), 141-146 (2011).

3. Pal, S., Tak, Y.K., and Song, J.M., Does the antibacterial activity of silver nanoparticles depend on the shape of the nanoparticle? A study of the gram-negative bacterium Escherichia coli., Appl. Environl. Microbiol, 73, 1712-1720 (2007).

4. Parameswari, E., Udayasoorian, C., Sebastian, S.P. and Jayabalakrishnan, R.M. The bactericidal potential of silver nanoparticles., Int. J. Res. Biotechnol. 1(3),44-49 (2010).

5. Brigger, I., Dubernet, C. and Couvreur, P., Nanoparticles in cancer therapy and diagnosis., Adv. Drug Delivery Rev. 54,631-651 (2002).

6. Amer, H.A., The study of silver and gold nanoparticles effect against local bacteria., Eng. \& Tech. Journal, 33 (4), 631-639 (2015).

7. Ip, M., Lui, S.L., Poon, V.K., Lung, I. and. Burd, A., Antimicrobial activities of silver dressings: an in vitro comparison. J. Med. Microbia, 55 (1), 59-63 (2006).

8. Assar, Nouran and Hamouda, Hayam H., Colloidal silver as a new antimicrobial agent., Int. J. Microb, Res. 1(1), 33-6 (2010).

9. Feng, Q.L., Wu, J. and Chen, G.Q., A mechanistic study of the antibacterial effect of silver ions on Escherichia coli and Staphylococcus aureus., J. Biomed. Mater. Res. 52, 662-668 (2000).

10. Lansdown, A.B., Silver. I: Its antibacterial properties and mechanism of action. $J$. Wound Care1. 1 (4), 125-130 (2002).

11. Brown, M.R. and Anderson, R.A., The bactericidal effect of silver ions on Pseudomonas aeruginosa, J. Pharm. Pharmacol. 20, Suppl: 1 S+ (1968).

12. Kim, S.H., Hyeong-Seon, L, Deok-Seon, R, Soo-Jae Choi and Dong-Seok, L., Antibacterial activity of silver-nanoparticles against Staphylococcus aureus and Escherichia coli Korean., J. Microbiol. Biotechnol. 39 (1), 77-85 (2011).

13. Morones, J.R., Elechiguerra, J.L., Camacho, A., Holt, K., Kouri, J.B., Ramirez, J.T. and Yacaman, M.J., Nanotechnology, 16 (10), 23-46 (2005).

14. Raffi, M., Hussain, F., Bhatti, T.M., Akhter, J.I., Hameed, A. and Hasan, M.M. Antibacterial characterization of silver nanoparticles against E. Coli ATCC-15224. J. Mater. Sci. Technol. 24 (2), 192-196 (2008).

Egypt. J. Biophys. Biomed. Engng. Vol. 17 (2016) 
15. DerChi, T., Liang, C., Nguyen, V. and Sana, A., Study of Ag and Au nanoparticles synthesized by Arc discharge in deionized water., Journal of Nanomaterials., Article ID 634757, 9 pages (2010).

16. Klein, E, Smith, D.L. and Laxminaryan, P., Hospitalization and death caused by Methicillin-Resistant Staphylococcus.aureus., United States, 1999-2005. Emerg Infect Dis. 13 (12), 1840-1846 (2007).

17. Simor. A.E., Containing methicillin-resistant $S$. aureus. Surveillance, control, and treatment methods, Postgard Med ., 110 (4), 43-48 (2001).

18. Saravanan, M., Biosynthesis and in-vitro studies of silver Bio-nanopaticles synthesized from Aspergillus species and its antimicrobial activity against multi drug resistant clinical isolates, World Academy of Science Engineering and Technology, 68, 728-31 (2010).

19. Rachel, C., Richard, A., Haverkamp, G. and Pak-Lam, Y., Investigation of morphological changes to Staphylococcus aureus induced by ovine-derived antimicrobial peptides using TEM and AFM FEMS., Microbiology Letters, 240, 105-110 (2004).

20. Lok, C.N., Ho, C.M., Chen, R., He, Q.Y, Yu, W.Y. and Sun, H. et al., Proteomic analysis of the mode of antibacterial action of silver nanoparticles., J. of Proteomic Research, 5, 916-924 (2006).

21. Sahar, E.A., Hussein, A.M. and Marzoga F.R., Effects of electric field on histopathological study, electrical properties and enzymes function of liver of albino rats., Research Inventy: International Journal of Engineering and Science, 4 (12), 2537 (2005).

22. Gelman, A., Analysis of variance? Why it is more important than ever, The Annals of Statistics, 33, 1-53 (2005).

23. Gelman, A., "Variance, Analysis of The new Palgrave Dictionary of Economics" $2^{\text {nd }}$ (ed). Basingstoke, Hampshire New York: Palgrave Macmillan (2008).

24. Ali, F. M., El_Khatib, A. M., Sabry, S.A., Abo_Neima, S. E. and Motaweh, H. A., Control of Staphylococus aureus by electromagnetic therapy, J. Natural Science, $\mathbf{1 5 5}$ (6), 169-177 (2013).

(received 8/ 3/2016;

accepted $18 / 10 / 2016)$ 


\section{دراسة تأثير جسيمات النانومتريه من الفضة كمادة مضادة للبكتريا

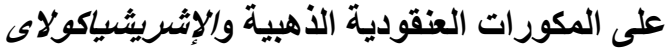

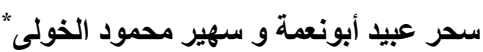

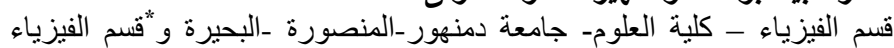

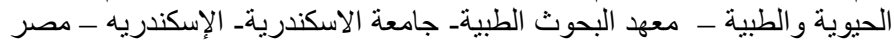

أجرى هذا البحث لدر اسة الأنشطة المضادة للبكتريا باستخدام الفضة كمادة فى أبعاد

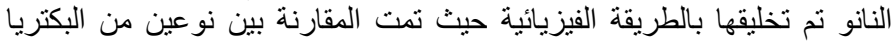

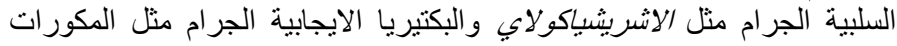

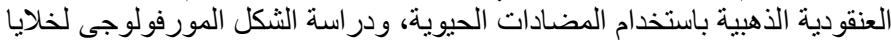

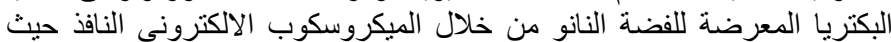

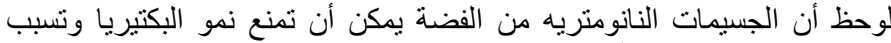

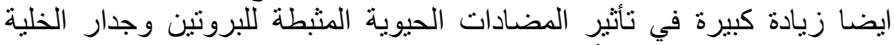

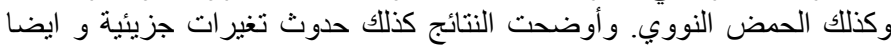

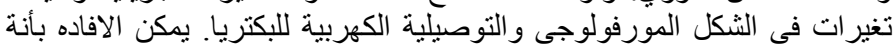

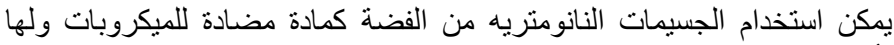
تأثير فعال كبير على الكائنات الحية الدقيقة. 